\title{
AN EDUCATIONAL GAME APPLICATION TO ASSIST THE COMMUNITY IN REMEMBERING ROAD DIRECTIONS AND PLACES IN PALEMBANG
}

\author{
Nadya Angelia1, Miftahul Jannah ${ }^{2}$, Albert Amadeus Valentino ${ }^{3}$, Michelle Liu ${ }^{4}$, Ali Ibrahim ${ }^{5^{*}}$ ) \\ 1,2Informatics Engineering Study Program, ${ }^{3}$ Medical Education Study Program, ${ }^{4}$ Dentistry Study Program, \\ ${ }^{5}$ Information Systems Study Program, 1,2,3,4,5 Multimedia and Game Programming Laboratory \\ Universitas Sriwijaya \\ https://unsri.ac.id/ \\ nadya.angel126@gmail.com¹, Mhjannah7463@gmail.com², albert.amadeus.valentino@gmail.com³ \\ liumichelle1707@gmail.com4, aliibrahim@unsri.ac.id ${ }^{5 *}$
}

(*) Corresponding Author

\begin{abstract}
Abstrak
Kemampuan visuospasial merupakan salah satu aspek penting dalam kehidupan sehari-hari, baik itu untuk bepergian ke suatu tempat ataupun untuk mengenali letak benda di sekitar. Kemampuan ini dapat ditingkatkan dengan menggunakan banyak cara, salah satunya dengan menggunakan repetisi. Aplikasi WorldVenture dibuat untuk membantu penggunanya meningkatkan kemampuan visuospasial dengan mengingat letak-letak tempat di kota tempat tinggalnya. WorldVenture dibuat dengan menggunakan framework flutter dalam lima tahapan, yaitu persiapan studi literatur, pengumpulan data dan informasi, perancangan sistem aplikasi, uji coba, dan evaluasi. Aplikasi ini akan memiliki tiga fitur utama, yaitu Flashcard, Kuis, dan Notes. Hasil pengujian aplikasi WorldVenture dengan menggunakan kuesioner menunjukkan hasil 64,5\% orang dari 30 responden menilai aplikasi WorldVenture sangat baik untuk meningkatkan kemampuan visuospasial dan sebanyak 35,5\% responden menilai baik.
\end{abstract}

Kata kunci: Kemampuan visuospasial, game edukasi, aplikasi, WorldVenture

\begin{abstract}
Visuospatial processing is one of the important aspects of everyday life, whether it is to travel or to recognize the location of objects around. Visuospatial processing can be improved in various way, one of which is by using repetition. WorldVenture app was created to help its users improve their visuospatial capability by remembering landmarks in the city where they live. WorldVenture was created using flutter framework with five steps, namely literature study, data and information collection, application designing, testing, and evaluation. This app will have three main features: Flashcard, Quiz, and Notes. WorldVenture testing result, using questionnaires, showed $64,5 \%$ people out of 30 respondents rated WorldVenture excellent for improving visuospatial capabilities and as many as $35.5 \%$ of respondents rated it good.
\end{abstract}

Keywords: Visuospatial processing, Educational game, app, WorldVenture

\section{INTRODUCTION}

Visuospatial processing is referred to as the brain's function in transforming visual input into three-dimensional reality (Groome, 2021). Visuospatial abilities are considered as crucial components of memory measurement and cognitive function, specifically in remembering information about objects, distances, colors, and visually reconstructing the environment. These visuospatial abilities are highly required in everyday life. Insufficient visuospatial abilities will lead to the individual not being able to lift objects, avoid surrounding objects, read maps, and remember places. These abilities are considered major in life, nonetheless, good visuospatial abilities are not likely to be possessed by all individuals.

In this era of globalization, technology has been widely used to assist people with low visuospatial abilities to find directions and places, such as by using the Global Positioning System (GPS), which can be accessed by using a smartphone. The use of GPS is considered capable of disturbing driving concentration, because the driver's focus will tend to be distracted by the smartphone being used (Lin, A. Y., Kuehl, K., Schöning, J., \& Hecht, 2017). Thus, it may raise the risk of a vehicle accident.

Visuospatial ability will likely decline with age (Kumar \& Priyadarshi, 2013; Mammarella, Borella, Pastore, \& Pazzaglia, 2013). This may be the result of the sensory system, which also declines with 
aging (Wingfield, Tun, \& McCoy, 2016). Visuospatial ability can be improved in several ways, specifically through repetition method (Baars \& Gage, 2010; Smyth, Jennings, Bennett, \& Birrell, 2021). Referring to research conducted by Lange-Küttner \& Küttner, visuospatial learning carried out on children aged 79 years by means of the repetition method was found to succeed in increasing the ability to remember the location of objects (Lange-Küttner \& Küttner, 2015). Moreover, research conducted by Stepankova et al. also managed to observe an increase in the visuospatial ability of adults aged 6574 years who participated in repetitive visuospatial training. (Stepankova et al., 2014)

The results of this research indicated that visuospatial learning through the repetition method was capable of improving one's memory. Furthermore, the memory was found to increase with increasing duration and the number of repetitions performed. Learning with repetition may be conducted in various ways, particularly by using flashcards or quizzes. The use of Flashcards is able to show good results in increasing memory (Glover, McLaughlin, Derby, \& Gower, 2010). In addition, memory ability may also be enhanced by using note-taking method (Bohay, Blakely, Tamplin, \& Radvansky, 2011)

In line with the description of the problem above, the authors had accordingly developed an educational game application called "WorldVenture", to assist users remember directions and places in Palembang. This application is designed with Flashcard and Quiz features that are capable of assisting users in forming visuospatial memories. The WorldVenture application is expected to improve user memory regarding road routes and various locations in Palembang, thereby reducing the number of accidents caused by the use of smartphones.

\section{RESEARCH METHOD}

\section{Types of Research}

This research was conducted through quantitative analysis method, involving data derived from surveys of several respondents related to the level of public knowledge about places in Palembang. Furthermore, quantitative analysis method was also utilized to measure the effectiveness of the WorldVenture application prototype in assisting people remember directions and places in Palembang.

\section{Research Time and Place}

The research was performed from June to August 2021. In addition, data collection, prototyping, testing and evaluation of this research were carried out successfully at the homes of each researcher.

\section{Research Target}

The subjects involved in this research were the general public, both in Palembang and outside Palembang, from teenagers to adults with a minimum age of 16 years. Subject data were collected and analyzed by means of Google Forms. Subjects were determined by utilizing the random sampling method, where everyone in the entire population was selected at random and had an equal chance of being selected as a research subject.

\section{Procedure}

The prototyping of the WorldVenture application is carried out in 5 stages, specifically:

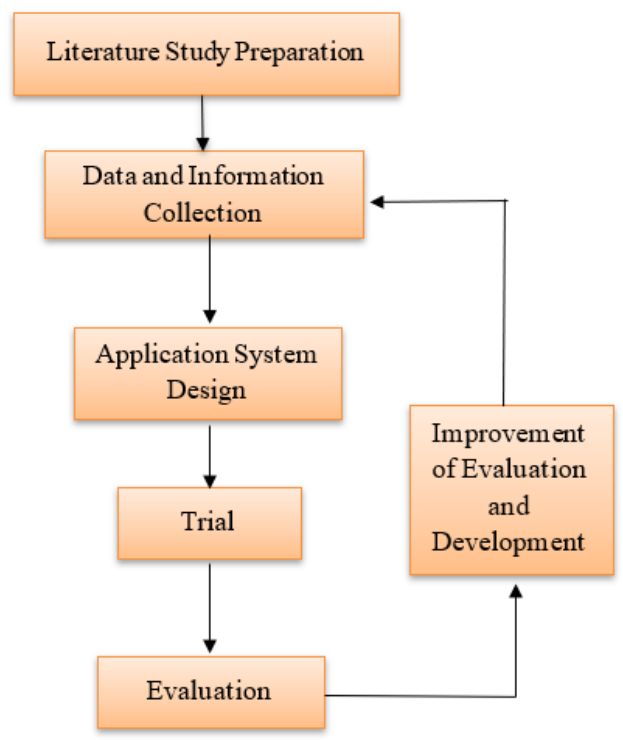

Figure 1. Flowchart of WorldVenture app creation follows:

The stages of creating the application are as

1. Literature Study Preparation

At this stage, the authors performed a literature study of various places and roads in Palembang, both frequently visited and rarely visited. Subsequently, the names of the places and roads would be recorded one by one.

2. Data and Information Collection

Data and information related to places and roads in Palembang were collected through questionnaires that had been distributed. The data included photos of places or roads, locations, and place names.

3. Application System Design

WorldVenture application prototype design was initiated by creating UI/UX designs through Canva media. Subsequently, the authors 
implemented the design into a programming language. The World Venture app was developed by using Flutter, specifically an open-source framework created by Google. Flutter is capable of being used on Android, iOS, Windows, Linux, and MacOS operating systems. The design of this prototype was made by utilizing the Dart language as a programming language. In addition, the application coding process was carried out by means of Visual Studio Code software.

4. Trial

The Application Prototype Trial was conducted by asking several respondents to observe the operation of the WorldVenture application. Furthermore, respondents were asked to provide an opinion on the effectiveness of the application for them. Respondents would then be required to assess the WorldVenture application prototype based on the usability testing principles. Respondents would assess the functionality of the application and its user interface.

5. Evaluation

The authors evaluated the success rate of the WorldVenture application prototype based on the trial results obtained. The results of the evaluation could be used for the development of application designs, thus causing WorldVenture to get maximum results.

\section{Data, Instruments, and Data Collection Techniques}

The data obtained in this research consisted of two: primary data and secondary data. Primary data included data on the level of community knowledge about places and directions in Palembang. Moreover, secondary data included the effect of environmental enrichment on the development of the Hippocampus, layout design, color, and good layout for the application. Research data were collected through a questionnaire instrument. Questionnaires were used to collect data from respondents regarding the level of community knowledge about directions and places in Palembang. The data collection technique used were questionnaires. The data in this research were collected by using a closed questionnaire technique, thus respondents might answer questions based on the answers provided by the researchers.

\section{Data Analysis Technique}

The data in this research were analyzed by utilizing descriptive analysis, thus, the generated data were in the form of numbers and percentages. Data were also presented in graphical form in the categories of WorldVenture's Level of Effectiveness in Ability to Remember Directions and Places in Palembang, WorldVenture's Level of Effectiveness in Assisting Spatial and Directional Abilities, Attractive and Easy-to-Understand User Interface, and Most Useful Features in WorldVenture Application Prototype.

\section{RESULTS AND DISCUSSION}

\section{Application System Design}

The prototype of the WorldVenture application was made by designing the appearance of the application and involving a number of data for places in Palembang. The data would then be accessed by WorldVenture users in a simple game. The WorldVenture application consists of three main features, namely Flashcard, Quiz, and Notes. The application display design was created by using Canva media. The form of some views of the WorldVenture application can be seen in the following figure:
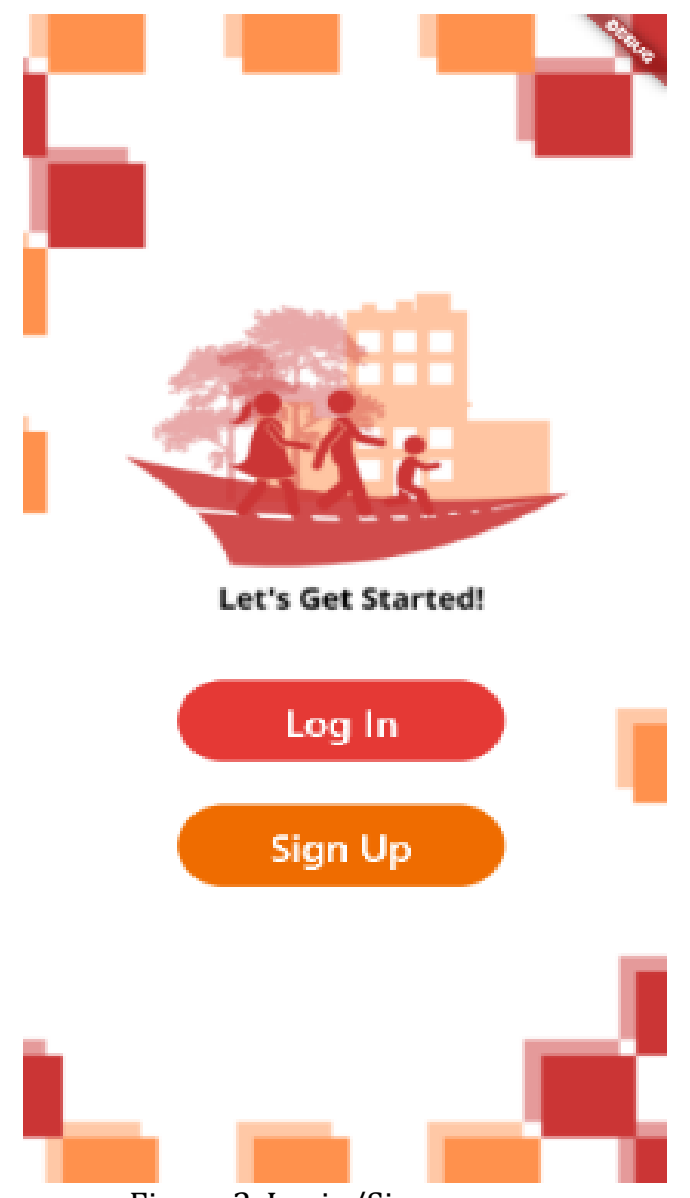

Figure 2. Login/Sign up page.

The Log in/ Sign up page consists of two options, specifically Log in for previously registered users and Sign up for users who are using the WorldVenture application for the first time (Figure 2). 


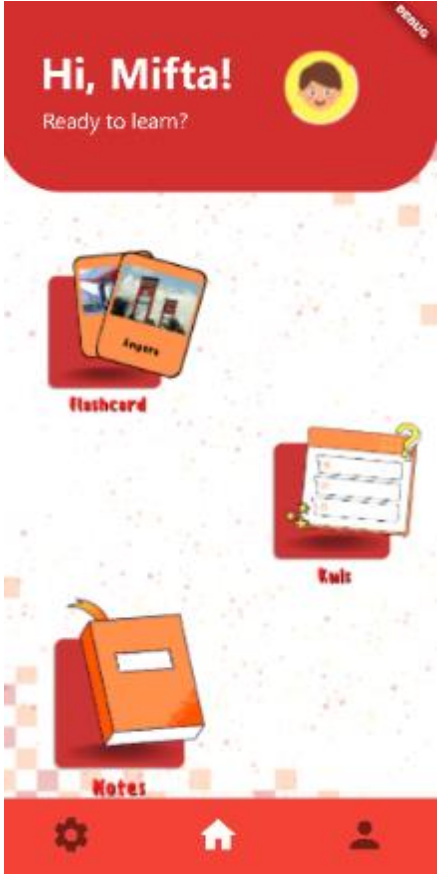

Figure 3. Main Page
Subsequently, the users will be directed to the main page (Figure 3), which provides three main features of the WorldVenture application, namely Flashcard, Quiz, and Notes.

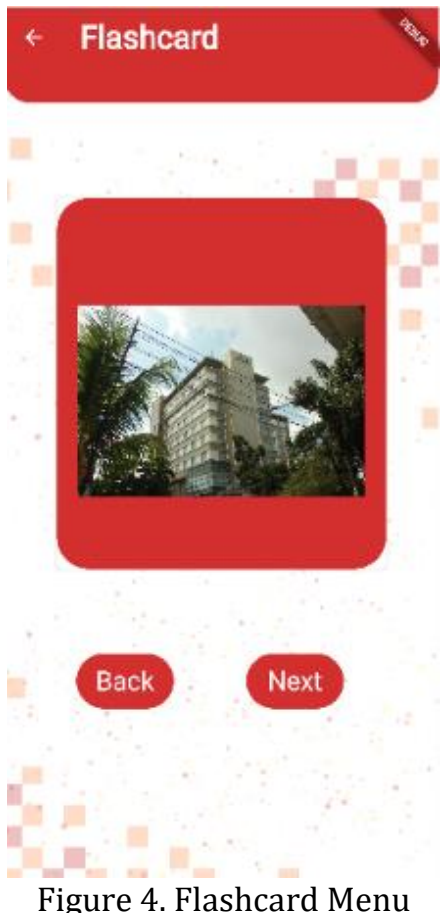

Figure 4. Flashcard Menu

The Flashcard feature consists of pictures of locations in Palembang along with information about the address and description of the location (Figure 4).

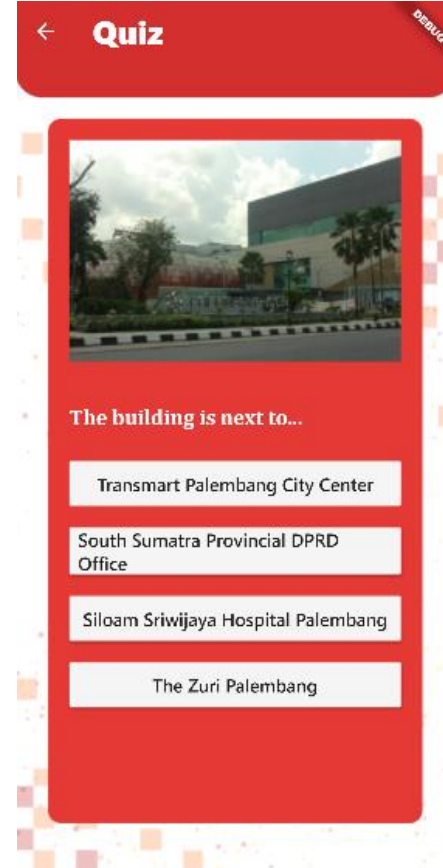

Figure 5. Quiz Menu

Furthermore, the Quiz feature consists of questions about locations in Palembang with multiple-choice answers (figure 5).
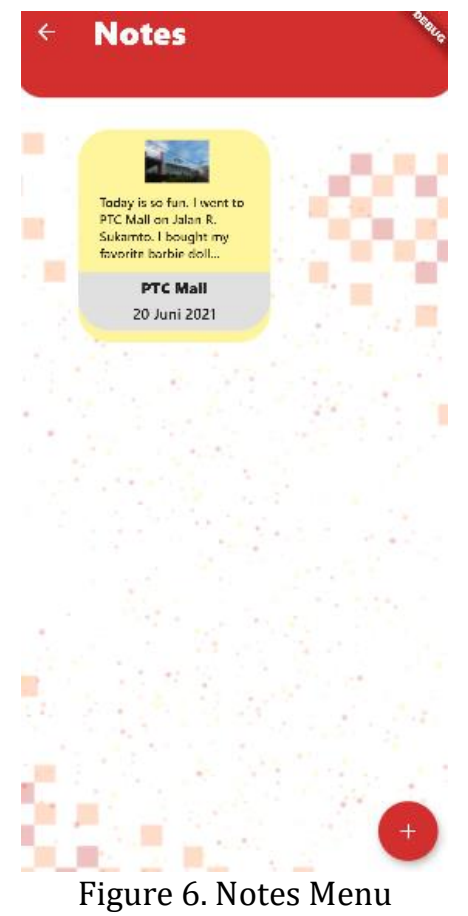

The last feature is the Notes feature, which allows users to add notes and pictures regarding the locations visited in Palembang (Figure 6). 
The display design of the application that had been designed, would be made in a programming language into a WorldVenture application.

\section{Testing and Evaluation}

The testing in this research was conducted based on the usability testing principle, namely by identifying the level of users' convenience and satisfaction with the effectiveness of the application in assisting users achieve their goals. Test results can be seen in the following diagram:

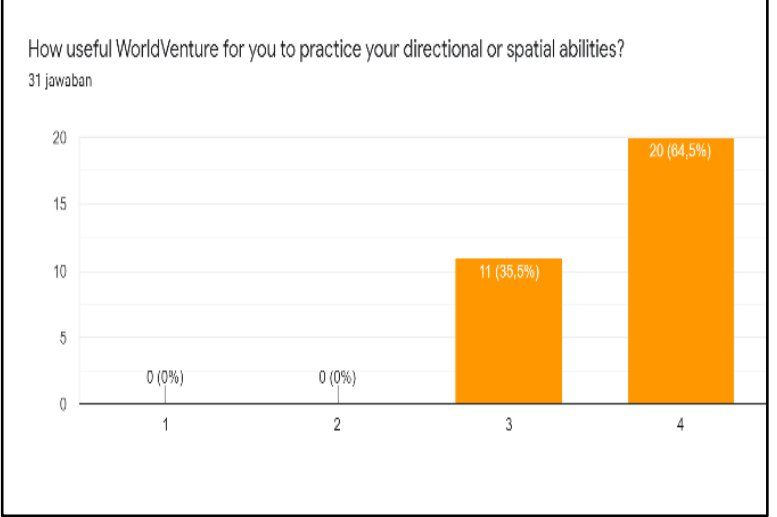

Figure 7. Result of questionnaires related to the effectiveness of the WorldVenture application in training memory and spatial abilities. 1) Not Good, 2) Fair, 3) Good, 4) Very Good.

The prototype of the WorldVenture application was considered fairly effective in training directional memory and spatial abilities. This was indicated by $35.5 \%$ of respondents who answered "good" and $64.5 \%$ of respondents who answered "very good" (Figure 7).

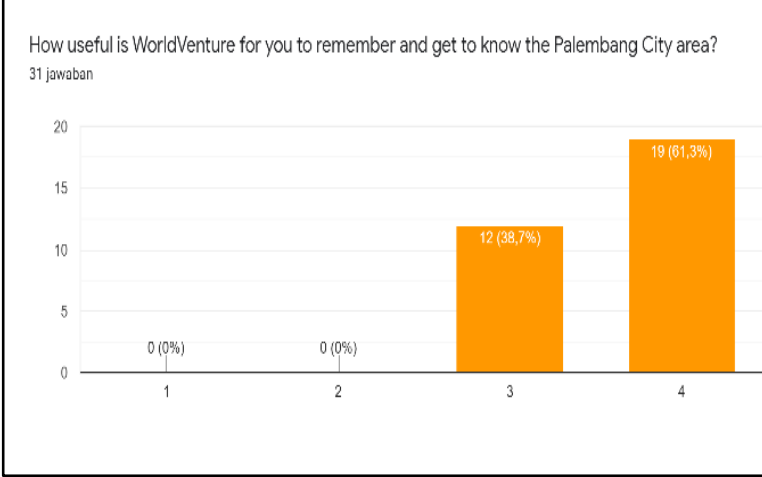

Figure 8. Result of questionnaires related to the effectiveness of the WorldVenture application in assisting users remember places in Palembang. 1) Not Good, 2) Fair, 3) Good, 4) Very Good.

Furthermore, the WorldVenture application prototype was considered useful for recognizing and remembering places in Palembang, which was indicated by $38.7 \%$ of respondents answered "good" and $61.3 \%$ of respondents answered "very good" (Figure 8).

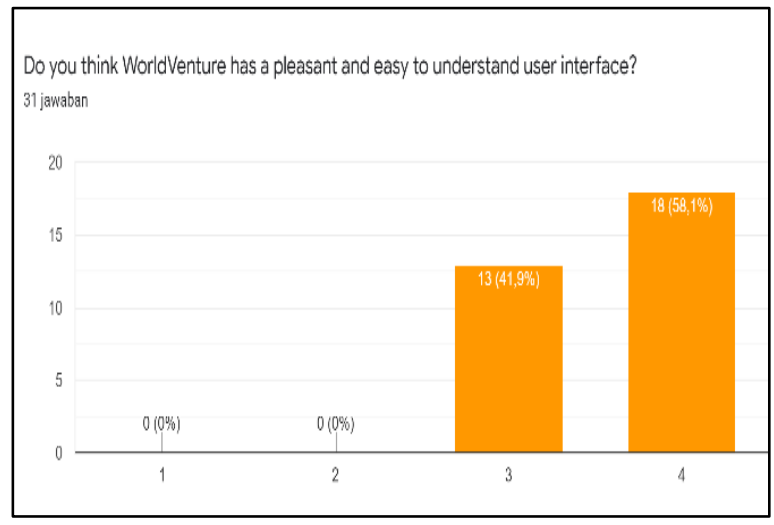

Figure 9. Result of questionnaires regarding the appearance of the WorldVenture application. 1)

Not Good, 2) Fair, 3) Good, 4) Very Good.

The prototype of the WorldVenture application also proved to be fairly effective to understand, this was indicated by $41.9 \%$ of respondents answered "good" and 58.1\% of respondents answered "very good" (Figure 9).

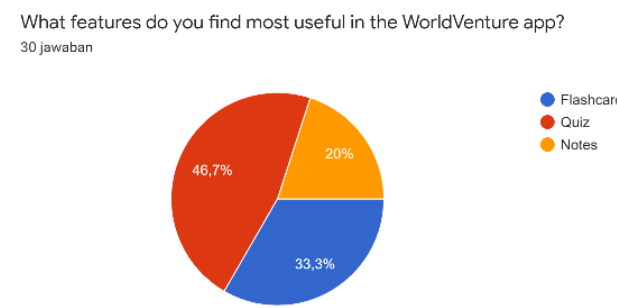

Figure 10. Result of questionnaires regarding the effectiveness of the WorldVenture features

Referring to the features that have been provided, the Quiz feature was chosen by users as the most useful feature to train memory and spatial abilities with a percentage of $46.7 \%$ (Figure 10).

\section{CONCLUSION AND SUGGESTION}

\section{Conclusion}

The WorldVenture app consists of three main features, specifically Flashcard, Quiz, and Notes. The WorldVenture application was developed to assist users in remembering directions and places in Palembang, as well as to practice visuospatial abilities. Having regard to the results of the tests carried out, the quiz, flashcards, and notes features were found to be effective in increasing the users' memory of directions and places in Palembang. 


\section{Suggestion}

Further research is recommended to reproduce data on various places and roads in Palembang. If possible, the features of places and roads in cities other than Palembang can also be added.

\section{REFERENCES}

Baars, B. J., \& Gage, N. M. (2010). Cognition, Brain, and Consciousness: Introduction to Cognitive Neuroscience - Bernard J. Baars, Nicole M. Gage - Google Books (2nd ed.). San Diego: Elsevier Ltd. https://doi.org/10.1016/C20090-01556-6

Bohay, M., Blakely, D. P., Tamplin, A. K., \& Radvansky, G. A. (2011). Note taking, review, memory, and comprehension. American Journal of Psychology, 124(1), 63-73. https://doi.org/10.5406/AMERJPSYC.124.1.0 063/0

Glover, P., McLaughlin, T., Derby, K. M., \& Gower, J. (2010). Using a Direct Instruction Flashcard System with Two Students with Learning Disabilities. Electronic Journal of Research in Education Psychology, 8(21), 457-472. https://doi.org/10.25115/EJREP.V8I21.1381

Groome, D. (2021). An introduction to cognitive psychology: Processes and disorders. New York: Routledge. https://doi.org/10.4324/9781351020862

Kumar, N., \& Priyadarshi, B. (2013). Differential Effect of Aging on Verbal and Visuo-Spatial Working Memory. Aging and Disease, 4(4), $170 . \quad$ Retrieved from /pmc/articles/PMC3733580/

Lange-Küttner, C., \& Küttner, E. (2015). How to learn places without spatial concepts: Does the what-and-where reaction time system in children regulate learning during stimulus repetition? Brain and Cognition, 97, 59-73. https://doi.org/10.1016/J.BANDC.2015.04.0 08

Lin, A. Y., Kuehl, K., Schöning, J., \& Hecht, B. (2017). Understanding" Death by GPS" A Systematic Study of Catastrophic Incidents Associated with Personal Navigation Technologies. CHI '17: Proceedings of the 2017 CHI Conference on Human Factors in Computing Systems, 1154-1166. Denver Colorado: ACM Press. https://doi.org/10.1145/3025453.3025737

Mammarella, I. C., Borella, E., Pastore, M., \& Pazzaglia, F. (2013). The structure of visuospatial memory in adulthood. Learning and Individual Differences, 25, 99-110. https://doi.org/10.1016/J.LINDIF.2013.01.0 14

Smyth, J., Jennings, P., Bennett, P., \& Birrell, S.
(2021). A novel method for reducing motion sickness susceptibility through training visuospatial ability - A two-part study. Applied Ergonomics, 90, 103264. https://doi.org/10.1016/J.APERG0.2020.103 264

Stepankova, H., Lukavsky, J., Buschkuehl, M., Kopecek, M., Ripova, D., \& Jaeggi, S. M. (2014). The malleability of working memory and visuospatial skills: a randomized controlled study in older adults. Developmental Psychology, 50(4), 1049-1059. https://doi.org/10.1037/A0034913

Wingfield, A., Tun, P. A., \& McCoy, S. L. (2016). Hearing Loss in Older Adulthood: What It Is and How It Interacts With Cognitive Performance. Current Directions in Psychological Science, 14(3), 144-148. https://doi.org/10.1111/J.09637214.2005.00356.X 